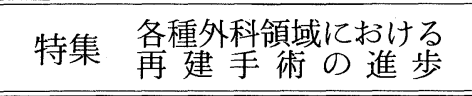

順天堂医学 $37(3)$

P. $366 \sim 376(1991)$

\title{
舌・口腔底悪性腫瘍術後の再建術**
}

\section{Reconstruction of tongue and oral floor cancer}

桜井淳*1) 市川銀一郎*1) 芳川 洋*1)

Atush SAKURAi M.D. Ginichiro ICHIKAWA M.D. Hiroshi YoshiKaWA M.D. 梁井晈*2) 吉方

Akira Yanai M.D. Rie YoshiKata M.D. Hisakazu SENo M.D.

井上雅博*2) 村 石世志野*2)

Masahiro INOUE M.D. \& Yoshino MURAishi M.D.

舌・口腔底悪性腫瘍の治療に当たっては, 悪性腫瘍の根治性とともに機能保全が重要な問題 となる. 近年われわれは舌・口腔底覀性腫瘍の切除術後に, マイクロサージャリ一による再建 術を取り入れることにより，拡大手術が可能となり良好な手術成績を得た。1989年から1991年ま での 8 例の再建例の検討では, ほぼ満足のいく結果であった。

本稿では舌癌・口腔底癌の症例をそれぞれ 1 例ずつ提示し, 実際の手術法について紹介した。 また, 現在に至るまでの舌・口腔底再建の変遷注対しての文献的考察を加え, また, 現在最も多 用されている遊離前腕皮弁による手術の特徴についての検討を行った。

索引用語：舌癌, 口腔底癌, 再建術, 遊離前腕皮弁, 微小外科

Key words : tongue cancer, oral floor cancer, reconstruction, free forearm flap, microsurgery

\section{はじめに}

舌・口腔は, 咀嚼・曣下・構音という重要な機 能を有する組織であり, 舌・口腔底の悪性腫瘍の 治療に当たっては, 悪性腫瘍の根治性とともに機 能保全が重要な問題となる.

舌・口腔底覀性腫瘍の手術では, 局所腫瘍を摘 出する際, 健常組織を含めて切除するため組織欠 損が生じ, 当然のことながら程度の差はあるが

* 1) 順天堂大学医学部耳鼻咽喉科学講座

Dept. of Otorhinolaryngology Juntendo University, School of Medicine, Tokyo, Japan

*2) 順天堂大学医学部形成外科学研究室

Dept. of Plastic Surgery, Juntendo University, School of Medicine, Tokyo, Japan

* * 第257回順天堂医学会学術集会〔May 16, 1991 開催〕

[June 22, 1991 原稿受領〕
機能障害が出現してしまう.

治療法 ${ }^{1 \sim 4}$ 'は大別すると neo-adjuvant chem therapy を代表とする化学療法に手術・放射線: 法を併用し，縮小手術を行い機能温存をはかる 法と, 拡大手術を主体に放射線・化学療法を加户 手術の際に機能回復のために再建術を行う方法 に分かれている。

近年われわれは, 舌・口腔底悪性腫瘍摘出術 おいて, microsurgery を利用した再建術を行 ことにより良好な手術成績を得ており, 今回, 近経験した代表的な 2 症例について報告し, 文 的考察を試みた。

症例

症例 1

患者：59歳 男性 
主 訴: 舌・口腔底違和感, 左澒部腫瘤 現病歴：平成 2 年 10 月頃より舌・口腔底違和 感が出現したが, 軽度であったため放置. 平成 2 年11月頃より左䅡部に腫瘤を触知するようになっ たが, 痛みもないため放置. しかし次第に増大傾 向にあったため, 平成 2 年 12 月 6 日某病院を受診. 頚部穿刺細胞診にて class V. 精查加療の目的に て当院耳鼻咽喉科紹介され, 平成 3 年 1 月 18 日初 診, 2 月 4 日入院となった。

既往歴 : 頝椎・腰椎椎間板ヘルニア

家族歴：特記すべきことなし

入院時所見: 左舌縁, 後 3 分の 1 の部位に白苔 を伴った直径約 $7 \mathrm{~mm}$ の浅い潰瘍と, その約 1.5 $\mathrm{cm}$ 前方に直径 $3 \mathrm{~mm}$ の表面不整の白色隆起性病変 を認めた。乙れらの周囲は表面平滑であったが， 触診上は板状硬で筋層内への浸潤か疑われた（写 真- 1 ).

頝部リンパ節は左下顎直下に直径 $2.5 \mathrm{~cm}$ 大を 1 個, 胸鎖乳突筋前縁で舌骨の高さに $3 \mathrm{~cm} \times 2.5 \mathrm{~cm}$ 大を 1 個，オトガイ下部に $1 \mathrm{~cm} \times 1 \mathrm{~cm}$ 大を 1 個 それぞれ触知した。 これら 3 個のリンパ節は弾性 硬で可動性は良好であった（写真- 2).

X-P・CT 上, 下顎骨への浸潤は認められなかっ た. 舌生検では角化を伴った高分化型の扁平上皮 癌であった。

他にリンパ節は触知せず，また全身ガリウムシ ンチ・骨シンチ・胸腹部 X-P 等において遠隔転 移を疑わせる所見もなく, T 2 N 2 M 0 の stage IV と診断した。

手術所見 : 平成 3 年 2 月 27 日気管切開術, 舌部 分切除ならびに左頝部郭清術, 舌・口腔底再建術 を施行した. 舌は硬結部外側より約 $1 \mathrm{~cm}$ の safety margin をとり切除, またその下方に存在する舌 筋群・顎二腹筋・顎下腺 - 胸鎖乳突筋 - 内顤静脈 耳下腺の一部を切除し, リンパ節郭清を行った。

舌・口腔底再建は形成外科担当で行った。橈骨 遊離前腕皮弁を健側である右側の上甲状腺動静脈 と顕微鏡下で吻合し, 皮弁は舌・口腔底粘膜と縫 合した。

術後経過：術後 3 日目, 軽度の誤㫶性肺炎を

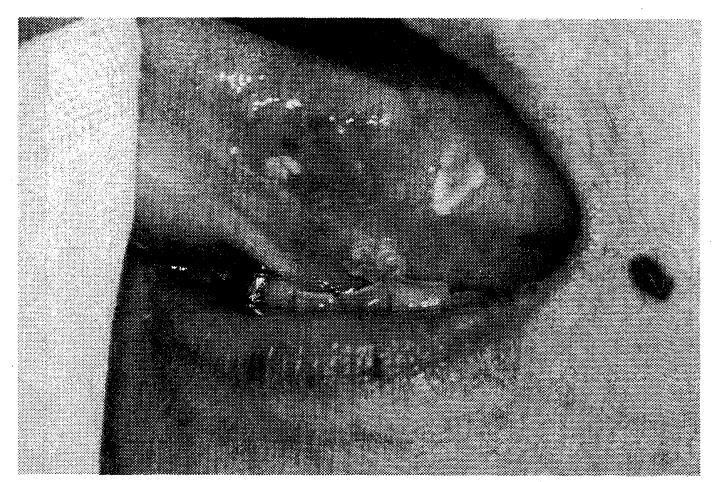

写真- 1 舌・口腔底所見

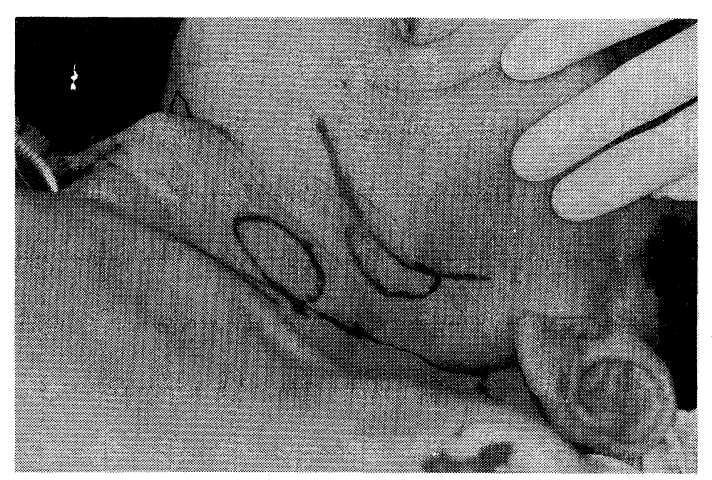

写真- 2 頝部リンパ節

合併したが, 抗生剂の点滴静注にて軽快, 次第に 曣下もうまくできるようになり，3月12日気管切 開孔閉鎖, 経口流動食開始, 3 月末には義歯装置 にて固形物摂取可能となった。 4 月 2 日よりカル ボプラチン $600 \mathrm{mg}$ ・ 5 -FU $4000 \mathrm{mg}$ を点滴静注, 一時, 血小板数・白血球数の低下をみたが回復. 5 月13日退院となった. 現在外来にて経過観察中 である。

症例 2

患 者：51歳 男性

主 訴：舌下部腫瘤・左顎下部腫瘤

現病歴：平成元年 1 月頃より舌下部違和感出 現するも放置. 4 月頃より舌下部に腫瘤を触知す るようになるが, 痛みもないため放置, 6 月頃よ り左顎下部に腫瘤を触知するようになったため近 医受診, 当院耳鼻咽喉科紹介され平成 
元年 6 月 16 日初診, 7 月 10 日精查加療目的にて入 院となった。

既往歴：25歳 急性肝炎

家族歴：特記すべきことなし

入院時所見 : 口腔底正中やや左寄りに2.7×1.8 $c m$ の比較的柔らかく易出血性の隆起性病変を認 めた．周囲は発赤と糜爛を呈していた（写真- 3 ). また，舌右縁に $1.2 \times 1.0 \mathrm{~cm}$ の白板症を認めた。

頝部リンパ節は顎下三角部に $2.5 \times 1.8 \mathrm{~cm}$ 大を 1 個触知し, また頝動脈分岐部直上に径 $1 \mathrm{~cm}$ 程度の 境界不明瞭で硬く, リンパ節転移を疑わせる部位 を 1 個認めた（写真-4）。他にリンパ節は触知せ ず，また遠隔転移を疑わす所見はなかった。

口腔底の擦過細胞診で class V, また顎下三角 部の穿刺吸引細胞診にて class Vの結果であった. また，白板症の部分の擦過細胞診は class II であっ た。頚動脈直上部は境界不明瞭で頚動脈に癒着し た印象があり，厚さもあまりなく，穿刺にて頝動 脈を傷つけてしまう危険が伴うため検索しなかっ た。病気分類は T 2 N 1 M 0 の stage III むし くはT2 N 2 M0の stage IVのいずれかという ことになり, UICC 分類規約に基づき stage IV と 診断した。

手術所見：平成元年 7 月 28 日, 気管切開術・口 腔底腫瘍摘出術 - 舌白板症摘出術 - 両側部分的頝 部郭清術, 舌・口腔底再建術を施行した。

口腔底は $1 \mathrm{~cm}$ 以上の safety margin をとった。 すなわち正中より左右に約 $3 \mathrm{~cm}$ ずつ, 後方は舌下 面 3 分の 1 まで, 前方は左右の第 1 ・第 2 門歯を 含み下顎骨上 3 分の 1 までの範囲を，下方にある オトガイ舌筋・オトガイ舌骨筋と一塊として切除 し，下顎骨内側表面を削開した。また，両側の顎 下腺, 上頝部のリンパ節ならびに脂肪組織を郭清 した。

舌・口腔底再建は形成外科で行った。橈骨前腕 遊離皮弁を右上甲状腺動静脈之顕微鏡下に吻合し, 皮弁は舌下面, 歯肉部粘膜と縫合した。

術後経過：術後 2 日目より誤曣による膿性の 喀痰, 発熱, 術創部の感染を併発したが, 抗生剂 点滴静注にて改善, 8 月13日歩行開始, 8 月15日

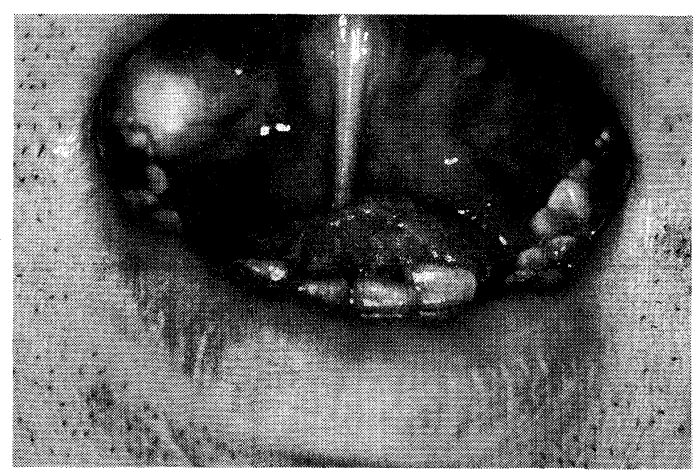

写真- 3 口腔底所見

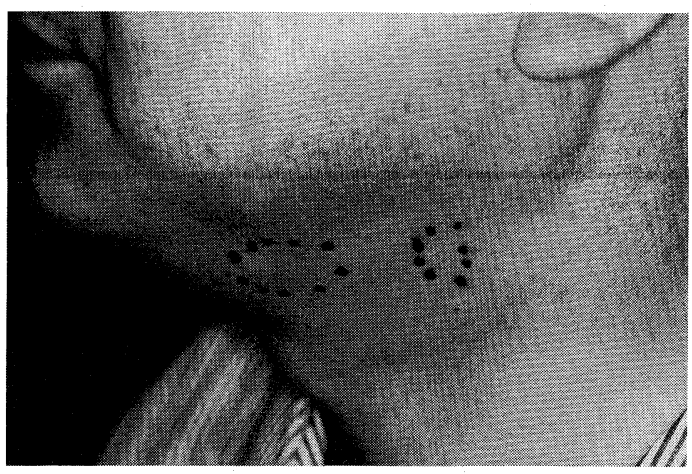

写真- 4 頝部リンパ節

気管カニューレ抜去し経口食を開始した。9月11 日からシスプラチン $100 \mathrm{mg}$ 点滴静注し, ペプロマ イシン $5 m g$ 筋注 5 日間を 2 クール施行した。

下顎欠損部に義歯を装着するととにより経口固 形物摄取も可能となり, また構音機能も良好とな り10月21日退院となった。

退院後外来にて経過観察されているが, 術後 2 年経過した現在も再発を疑わせる所見は見られて いない。

\section{最近の当院における再建手術例の内訳}

1989年から1991年までの 2 年間で, 当院で行わ れた舌・ 口腔底再建術の症例を表- 1 亿示す. 男性 6 名・女性 2 名で年齢層は 43 歳から64歳までであっ た. 原発部の大きさは再発例を除けばすべて最大 
表- 1 最近の当院における再建手術例

\begin{tabular}{|c|c|c|c|c|c|c|}
\hline №. & 名前 年 & E性 & 部位 & TNM & 再建 & 経過 \\
\hline 1 & T. M 59 & $9 \hat{0}$ & 舌 & T 2 N 2 M 0 & 前腕 & 0 年 2 月 \\
\hline 2 & \begin{tabular}{l|l} 
S. T & 51
\end{tabular} & $1 \hat{0}$ & 口腔底 & $\mathrm{T} 2 \mathrm{~N} 2 \mathrm{M} 0$ & 前腕 & 1 年10月 \\
\hline 3 & \begin{tabular}{l|l} 
T.S & 47
\end{tabular} & $7 \hat{0}$ & 口腔底 & T 2 N 2 M 0 再発 & 腹直筋 & 死亡 \\
\hline 4 & \begin{tabular}{l|l} 
K. O & 48
\end{tabular} & 8 今 & 舌 & $\mathrm{T} 2 \mathrm{~N} 0 \mathrm{M} 0$ & 前腕 & 1 年 2 月 \\
\hline 5 & A. $\mathrm{T} 51$ & 1 우 & 舌 & $\mathrm{T} 2 \mathrm{~N} 0 \mathrm{M} 0$ & 前腕 & 1 年 2 月 \\
\hline 6 & A. $M 64$ & $4 \hat{\circ}$ & 舌 & $\mathrm{T} 2 \mathrm{~N} 0 \mathrm{M} 0$ & 前腕 & 1 年 3 月 \\
\hline 7 & A. M 49 & 9 우 & 舌 & T $1 \mathrm{~N} 1 \mathrm{M} 0$ 再発 & 前腕 & 1 年 4 月 \\
\hline 8 & K. M 43 & $3 \hat{0}$ & 舌 & $\mathrm{T} 2 \mathrm{~N} 0 \mathrm{M} 0$ & 前腕 & 0 年10月 \\
\hline
\end{tabular}

径 $2 \mathrm{~cm}$ から $4 \mathrm{~cm}$ までのT 2 に分類された。病期分 類では stage II が 3 名, stage IIIが 2 名, stage IVが 3 名であった。乙の表は再建術を要した症例 の内訳であるが, 再建術を必要としなかった症例 は stage I が 2 名, stage IIが 1 名であった。

症例 3 を除けば現在なお生存中である。症例 3 は遠隔転移にて死亡したが, 原発部には再発を疑 わす所見なく，皮弁は全生着していた。症例 6 は 大胸筋皮弁を最初に用いたが生着せず, 後に前腕 遊離皮弁による再度再建術を施行した。症例 7 は 右舌部分切除ならびに右䅡部部分的郭清を施行し た症例であるが，オトガイ下に再発を認め，1回 目の手術の 9 力月後に舌 - 口腔底右半切除, 右下 顎骨部分切除, 右根治的頝部郭清を施行し, 前腕 遊離皮弁による舌・口腔底再建を行った。

症例 $1 ・ 2 ・ 3$ は stage IVの進展例であり, 症例 7 は再発例である. 当院耳鼻咽喉科では1989年以 前には拡大手術は行っていなかったが，てのよう に再建法を取り入れるようになって拡大手術を行 うことが可能となっている. また化学療法, とく に BLM・PEP の血管内皮に及ぼす影響が知ら れているが5゙ 7), 死亡した 1 症例を除いて全例に 化学療法を施行したが，乙の7例においてはすべ て全生着している。

\section{遊離前腕皮弁による再建術術式について}

橈骨前腕遊離皮弁を用いた再建について症例 1 を例にとって順を追って説明する。 ${ }^{81215}$

1 ）術前の準備
まず久損となる部位の大きさや組織の種類（骨・ 皮膚・筋肉・粘膜など）を知る必要がある。乙の 症例では前腕遊離皮弁で補える大きさであるか否 か, また下顎骨の切除を加えるか否か, 皮膚の欠 損があるか否かなどが問題となってくる．場合に よっては再建に用いる組織の変更を余義なくされ る可能性がある。また, 皮弁の採取は原則として 患者の利き腕でない側より行う。

次に移植床部となる血管が吻合可能であるかど うかを検討する. 動脈硬化や糖尿病などによる血 管自体の病変が無いかどうか, また血管の太さゃ 蛇行, 手術によって損傷を受ける可能性などが問 題となるため, 術前に両側䅡動脈のアンギオグラ フィーを撮影する。

前腕遊離皮弁採取部に関しては橈骨動脈を触知 し, Allen test を行い尺骨動脈のみで手への血行 が保たれることを確かめるだけで, 必ずしもアン ギオグラフィーを必要としない。

このようにして術前に予め遊離皮弁の構想をた てておく．また血管の損傷を避けるため，手術数 日前から皮弁をとる側の腕からの採血・注射は禁 しておく.

\section{2) 腫瘍摘出術}

この症例では舌腫瘍摘出術ならびに左頚部郭清 術を施行した。このときの舌部分切除をシェーマ で表す（図-1).すなわち, 舌本体に加え, 口腔 底粘膜・顎舌骨筋・顎下腺・顎二腹筋を同時に切 除した。このように大きく切除すると, 口腔底は 顎下部の皮膚のみとなり，大きな欠損が残って

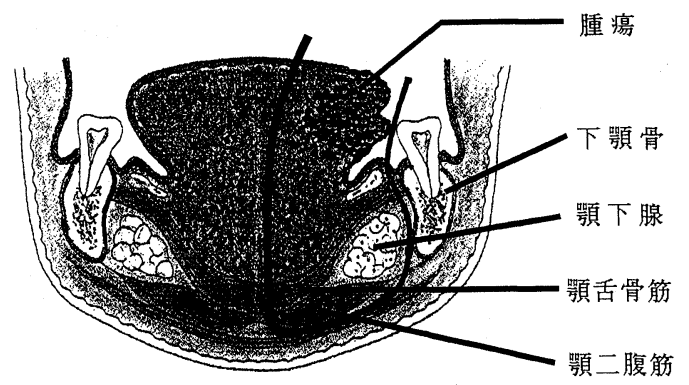

図- 1 切除範囲のシェーマ 
しまう、また口腔内であるため, 唾液・食物など に污染されやすいこともあり，また機能障害も起 てってしまうため, この欠損した部分を他のもの で補わなければならなくなる。 そてで再建術が必 要となる。この症例では橈骨前腕遊離皮弁による 舌・口腔底再建術を施行した。

\section{3 ) 再建術}

まず䅡部血管を露出する．乙の症例では患側で ある左側は䅡部郭清を行っており，適当な吻合血 管は確保できなかった，そてで健側の頝部より移 植床部の血管を露出させた，用いた血管は上甲状 腺動静脈であった。 上甲状腺動静脈のほかに，動 脈では顔面動脈・舌動脈・頚横動脈なども使用可 能である.しかし血管径が十分に大きく，緊張が かからない程度の長さが得られ, 血管露出が容易 な上甲状腺動脈・顔面動脈が使用されるととが多 い. また顔面動脈に並行して顔面神経が走行して おり，麻㽻の危険性があるとと，また吻合の容易 さ，吻合部を水平状態にすることができるととな どから，当院では可能な限り上甲状腺動脈を用い ている. 静脈では上甲状腺静脈のほかに外頝静脈・ 顔面静脈・前䅡静脈などが使われ，径の大きさや 位置, 頚部郭清による損傷などの要因から選択さ れる。

次脌前腕皮弁の作図をする（写真- 5 ）。皮弁の 大きさは, 舌・口腔底部欠損よりも余裕を持って やや大きめに作図する。この症例では採取した皮 弁の大きさは $8 \times 6 \mathrm{~cm}$ であった．前腕皮弁では手 関節部より肘窩付近まで, 大きさでは最大 $10 \mathrm{~cm}$ $20 \mathrm{~cm}$ までは採取可能と言われている。 また，皮弁 側の血管は橈骨動静脈であるが，乙の長さは移植 部である舌・口腔底欠損部と移植床部である上甲 状腺動静脈までの距離を測定し，その長さよりも やや長めにとる.

前腕皮弁を剥離し挙上する（写真- 6 ）。乙のと き出血量を少なくし，手術操作を容易にするため に上腕部に装着したターニケットを加圧して行う （200～250mmHg). 皮弁には筋膜も含まれる．た だし，腱の部分では腱周囲組織は残すようにする。 静脈は伴行動脈を用いた。伴行静脈のほかに正中

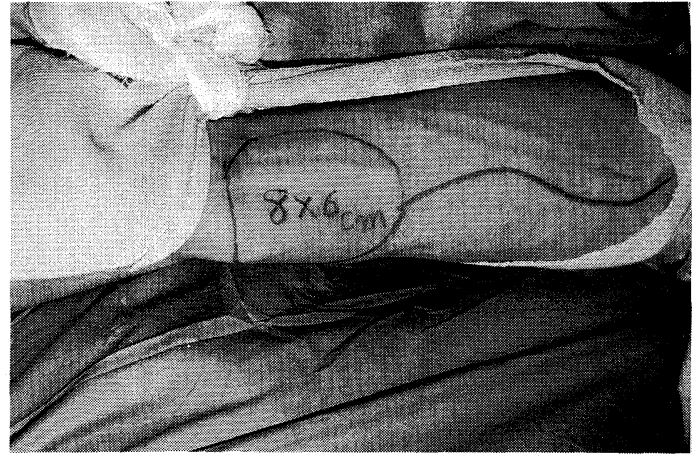

写真- 5 前腕皮弁の作図

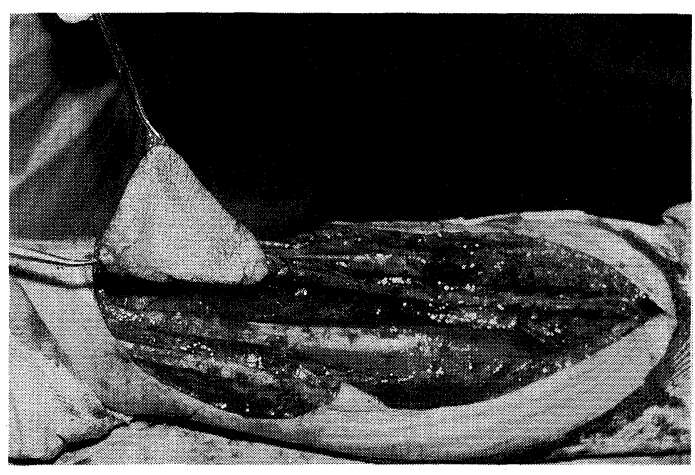

写真- 6 皮弁の剝離

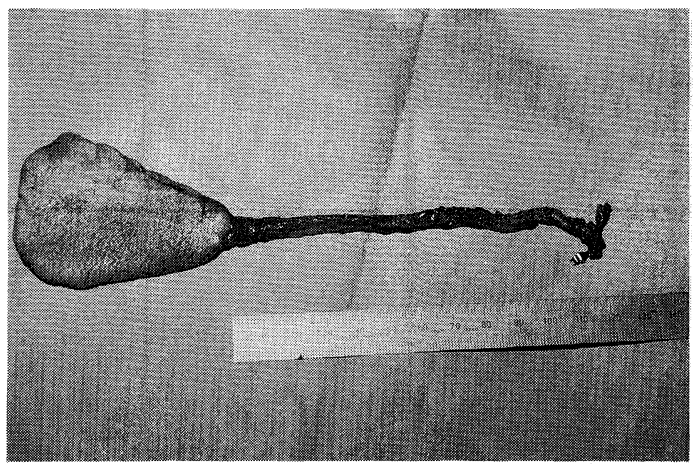

写真- 7 血管付き遊離皮弁

皮静脈を用いる場合もあるが，当院の例ではすべ て橈骨動脈に伴行する橈骨静脈を用いている．剥 離・挙上が終了したらターニケットを解除して止 血を確認し血管柄を切断する（写真- 7 ）。橈骨 


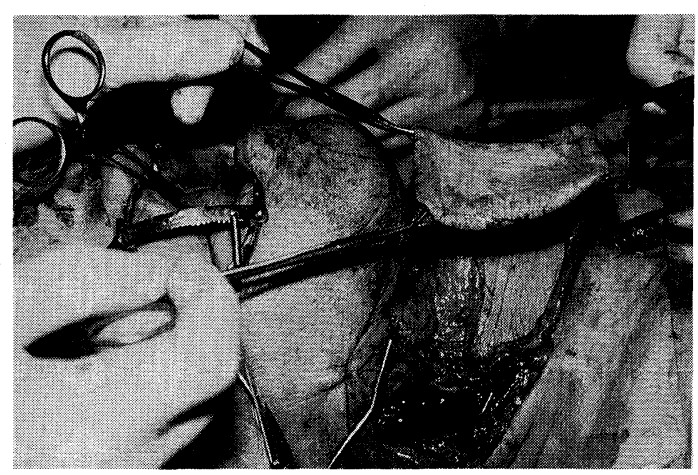

写真- 8 血管吻合後の皮弁の移動

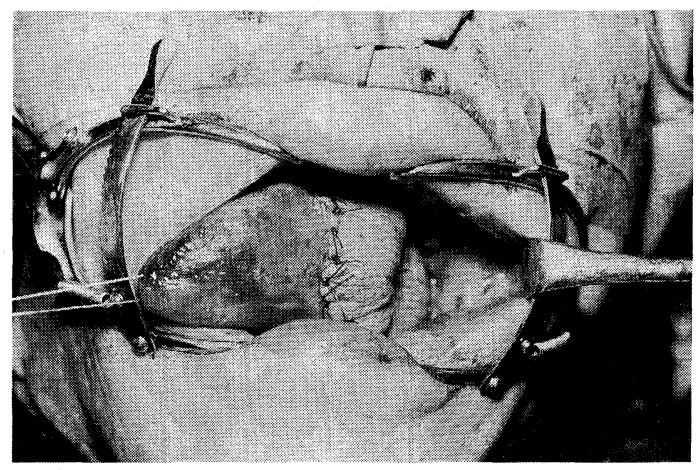

写真- 9 終了時の状態

動脈の欠損に対しては大伏在静脈などの静脈移植 を行った報告もあるが, 通常は移植なしでもほと んぞ機能障害は認めない. なお前腕から皮弁を採 取し皮膚欠損となった部分には大腿部より分層植 皮弁を採取し植皮する。そして，ターニケット使 用時間は 1 時間以内とし, それ以上かかる場合に は一旦ターニケットの圧を解除し，15分後に再度 ターニケットを使用する。

次に血管吻合を行う。手術顕微鏡下に動脈之静 脈とをそれぞれ 1 本ずつ行う. 吻合血管周囲結合 織を切除し, マイクロクリップをかけて 2 本の血 管の内膜が密着するように行う。縫合糸は10-0モ ノフィラメントナイロン糸を用い端々吻合を行う. 縫合は血管の太さによって多少異なるが, 前腕遊 離皮弁の場合だとおおむね動脈10針・静脈 8 針程 度であり，吻合血管に径の差がある場合には縫合
数が増加する ${ }^{16177)}$. 血管径の相異が 3 倍以内であ れば通常の端々吻合は可能であると言われてい る ${ }^{18)}$. また動脈の攣縮の予防のためキシロカイン を散布することもある. 血管吻合終了後, マイク ロクリップ除去し，縫合糸の間から明らかな血液 の漏洩がみられればその部位の追加縫合を行う。 開存試験を行い, 動脈の拍動や皮弁の色調などか ら血行が良好なととを確認する。

皮弁は左䅡部, および顎下部のトンネルを通し て舌・口腔底の欠損となった部分に移動し（写真8 ), 皮弁と舌・口腔底を縫合する. 欠損部に皮弁 を適合し, 余剰部の上皮を調整後に行う. 再建時 に血管柄が過度の緊張状態にならないてと, 血管 柄がねじれないように注意を払う。なお，血管柄 の長さに十分な余裕がある場合，または皮下トン ネルを皮弁を通せる程十分なおよび大きさで準備 できない場合は, 血管柄をトンネル内に通し縫着 後に血管吻合を行うことがある. 終了時の状態を 写真- 9 亿示す.

\section{4 ) 術後}

再建術術後に最も問題となるのは吻合血管の血 行障害である. 吻合部からの出血はもちろんであ るが, 血栓もまた多い合併症とされている. 動脈 の閉塞による虚血や静脈の閉塞によるうっ血であ る. 血栓が生じた場合皮弁全体が壞死を起しして しまうため,ただちに再手術が必要となる。多く の場合吻合血管の閉塞は術後 24 時間以内に生じて おり,それゆえ術後は慎重な管理が必要とされ， 血管吻合後 $3 \sim 4$ 時間の時点で皮弁の色調を観察 して血行状態を確認する ${ }^{19)}$. またドップラーを用 いて血流を確認したり，また移植した皮膚に細い 針を穿刺し出血を確認したりする（pin prick test）. 血栓の予防のために止血剤は使用しない.

\section{考察}

1 ）舌・口腔底再建の変遷

頭䅡部外科領域における再建の歴史は比較的新 しい. 1963年 McGregor ${ }^{201}$ の前額皮弁による再建 法を皮切りに, 1965年 Bakamjian ${ }^{21}$ は delto- 
pectral flap（以下 DP皮弁と略）を用い下咽頭 頚部食道再建を行い, 以来頭䅡部領域に広く用い られるようになった。特にDP皮弁による再建は 腫瘍切除範囲の拡大と手術自体の安全性をもたら しただけでなく，ある程度の機能回復が可能とな り本邦でも1970年松浦ら ${ }^{22}$ が発表して以来各施設 で用いられ，下咽頭䅡部のみならず上顎・下顎・ 舌・口腔・顔面と応用範囲が広く, 頭䅡部再建は 変貌を遂げた。

DP皮弁は大胸筋部から三角筋部にかけての皮 膚を用いたもので, 有茎のまま皮弁を移動させ欠 損部にあてるものである。

栄養動脈として内胸動脈の穿通枝を $3 \sim 4$ 本含 んでいる.また，血流動体からみてはっきりした 栄養動脈をもち主軸血行型皮弁（axial pattern flap）に属するが23)，三角筋部は random pattern flap であり, 先端部の壊死を起こしやすい241. のため, 腫瘍摘出術を施行する約 2 週間前に一旦 皮弁部を剥離し; 摘出術までの間に血流を回復さ せる“delay”を行う場合がある。また，皮弁が胸 部から直接有茎で再建部位に連なっているため, 数週後に皮弁の切離を必要とする. 再建の部位に よっては数次にわたる場合があるという欠点が ある。

前額皮弁は前額部の皮膚を患側煩骨弓下をくぐ らせ口腔内に到達させる方法である. 額・顔面の 修復に広く利用されたが，その特徵として ${ }^{25)}$, 安 全・確実で作成が容易であること, DP皮弁と比 較し術後の頚部固定が不要で頚部の運動が制限さ れないととなどの利点がある。しかし皮弁採取部 が顔面の一部であるため, 女性・青年男子には使 用し難く, また前額部の範囲に限界があり, 久損 部が大き(場合には使用し難(26) 28)と言われて いる。

そこで1970年代になってさらに大胆な再建法が 使用されるようになった。すすなち筋皮弁である. 筋皮弁は皮膚・筋肉を一塊として血管を有茎にし て用いるものである. 1978年 Quillen ${ }^{29}$ は広背筋 皮弁を，1979年 $\mathrm{McCraw} ら^{30}$ は僧帽筋皮弁を， Baeck ら ${ }^{31)}$, Ariyan ${ }^{32133)}$, Winthers $ら^{34)}$ は大胸
筋皮弁を用いた再建を相次いで発表し，また本邦 でも1979年坂東 ${ }^{35}$ 少発表して以来, DP皮弁の時 と同様またたく間に全国各施設で施行されるよう になった。

筋皮弁の特徵として坂東ら ${ }^{36}$ は, (1)筋およびそ の上部の皮膚を栄養する血管束が 1 箇所にまとめ て剥離でき, それのみで全体の血行が安定してい る,すなわち島状にできるので可動範囲が大きく 移動のための口スが少ない. (2) 1 期的再建がほと んどの場合可能. (3)局所解剖を熟知すれば手術的 操作は比較的簡単. (4)筋と血行のバリエーション がほとんどない，または術前に調べることができ る. (5)採取部位が 1 次的に縫合閉鎖可能で, 残る 変形が少ない,などの特徵をあげている。

また, 坂東らは広背筋皮弁に比較し大胸筋皮弁 は，(1)肋骨・肋軟骨を同時に筋皮弁につけて利用 できる. (2)筋の大部分は残すととができるので機 能障害が少ないと期待できる. (3)前胸壁・頭䅡部 の再建には体位変換が必要なく操作が楽であり, 手術時間を短縮できる，などの特徵をあげている.

また再建適応範囲がほぼ同じであるDP皮弁と 比較しても(1)血行がよく信頼性が高い. (2)Delay なしに移植できる. (3) 1 期的再建であり患者に不 都合な体位を強制しない. (4)頭䅡部郭清後の大血 管などを茎となる筋腹で被うことができ，胸鎖乳 突筋のようなシルエットが得られる。(5)術後の careも特別なととはない. 6採取部位の変形が目 だちにくい,などの特徴がある。

一方広背筋皮弁の長所として ${ }^{23 / 37)}$, 大胸筋ほど 筋肉の発達に variation がなく血行不良部位が 生じにくく, 大胸筋皮弁よりもさらに広範囲に及 ぶ再建が可能であり, 恵皮部がめだたなく美容上 適当であり，日常生活上運動障害も問題とならな いなどの点があげられる.

このように筋皮弁は頭䅡部領域の再建に多用さ れ，また胁骨や胸骨を利用した骨付き筋皮弁とし ても用いられ, さらに広大な範囲の再建が可能と なった。

しかし, 有茎であるためにその移動範囲が限ら れ，またDP皮弁ほどでないにしろ皮弁の壊死を 
起乙しやすいことなどの問題がある．そこで再建 材料を血管柄つき遊離組織片として利用する方法 が注目されてきた。しかし，遊離組織片を移植す るには血管吻合が必要である．筆者が調べた範囲 では1960年に Jacobson と Suarez ${ }^{15}$ がすでに顕 微鏡下で血管吻合を行っているが, 非常に熟練し た技術を要し, 再建外科での臨床応用が一般化す るととは困難であった。

しかし，1970年代になって再建外科の技術と器 具の進歩 ${ }^{38}$ によって遊離組織移植が可能となった。 技術が必要ではあるが同じ筋皮弁でも遊離移植の 形で行った方が術後成績は良好であり, 現在遊離 組織移植は再建外料の主流をなしていると言って も過言ではない。

梁井ら ${ }^{39}$ ' は頭頝部領域の再建における有茎筋皮 弁と遊離筋皮弁の比較検討を行った。 その結果， 有茎筋皮弁に比較して遊離筋皮弁は(1)部分壊死・ 完全壞死が少なく生着率が高い. (2)瘻孔形成率が 低く,また瘻孔形成したものでも術後 4 週間以内 に自然閉鎖する割合が高い. (3)経口摂取の開始時 期が早い. (4)筋皮弁の血行が良好. (5)十分な組織 量が採れるため死腔が少ない, などの特徵を有す ると述べている。

本稿では遊離前腕皮弁を中心に述べたが，遊離 筋皮弁は現在もなお利用されている ${ }^{32)}$. 舌・口腔 底再建に関しては dead space が大きい場合, 前 腕遊離皮弁よりも遊離腹直筋皮弁や遊離広背筋皮 弁などが適している。また，下顎骨に進展した場 合などは骨付き筋皮弁として遊離胸骨，さらに肋 骨付き大胸筋皮弁・遊離胁骨付き広背筋皮弁・遊 離肋骨付き前鋸筋皮弁などがあり，また1975年 Taylor ら ${ }^{40}$ が発表した遊離腸骨付きも用いられ ている.

遊離筋皮弁同様汸離皮弁 ${ }^{17}$ も用いられるよう になった。遊離皮弁には当症例で用いられた遊離 前腕皮弁の他に, 鼠径皮弁・足背皮弁・肩甲皮弁・ 胸三角皮弁なども用いられるが, 現在のとてろ遊 離前腕皮弁が最も多用されている。

皮弁および筋皮弁以外では, 遊離空腸が用いら れている(1) 44). この特徵として(1常に血流が安定
していて遷延治癒・瘻孔形成が少ない. (2)薄く・ 柔らかいためどのような複雑な欠損にもうまく適 合する. (3)かなり広い移植組織が準備できる. (4) 粘液の分泌によって常に移植組織面は清潔で放射 線などの影響による口腔乾燥が緩和される. (5)皮 弁のような痒痕がみられない，(6)機能回復, 創の 治癒が早い. (7)腹部であるので傷がめだたない. などの特徵があげられる。

一方, 短所としては(1)開腹術を必要とし手術侵 襲が大きくなる. (2)義歯の装着が困難である. (3) 一旦腹腔内の創の治癒不全が起てった場合, 侵襲 がさらに大きくなる. (4)顔面皮膚側の再建には応 用できない.などがあげられ，遊離組織としての 性能は非常に優れてはいるが; 現在のとてろ遊離 前腕皮弁を用いる症例の方が多いようである.

\section{2 ）遊離前腕皮弁の特徵}

遊離前腕皮弁は1978年中国の Yang らにより 熱傷疫痕の再建に用いられたのが最初で, 別名 Chinese flap と呼ばれている. この皮弁は数々の 長所を有し, Souter $ら^{45)}$ や高戸ら ${ }^{6}$ 少口腔内の再 建にてれを応用し, その有用性からまたたく間に 全国に広がり, 現在口腔底再建の主流となってい る. その特徵としては(6)7/9/23/46/47), (1)血管の走行 が解剖学的に安定しており, 皮弁採取が比較的容 易である. (2)皮弁が薄くしなやかであるため, 舌・ 口腔底のように可動性が要求される部位の再建に 応用しやすい. (3)橈骨動静脈・正中皮静脈は血管 が太く，また長い距離がとれるので皮弁の応用範 囲か広い. (4)血管が十分な太さを持っているため 血管吻合が比較的容易である. (5)口腔の粘膜欠損 の再建には十分な大きさの皮弁が得られる。 (6)術 野か顗䅡部と前腕とに分かれるため, 舌・口腔底 切除術と皮弁採取とが同時に進行できる. (7)切除 術をより徹底的・拡大的に行うことができるため, 進展例や再発例に応用でき治癒率の向上が期待で きる.88皮弁採取による手術侵襲が少ないため, 患者に対する負担が余りかからない. (9)またそれ ゆえ重篤な機能障害や合併症がほとんどない。 (10術後の経口摂取再開までの期間・入院を要す る期間が比較的短い。(11)術後の皮弁の収縮・ 
変形が少ない. 頚部では下肢などに比べて血流が

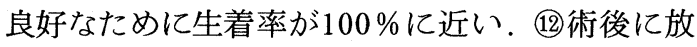
射線・化学療法を施行しても変形・壊死を起てし にくい. 13皮弁が薄くまた可動性に富むため, 残 存した舌の運動を妨害せず, 構音機能が保たれや すい. (14)舌・口腔底切除から再建まで一期的な手 術が可能である,などがあげられる。

一方, 短所としては28)49), 血管のマイクロサー シャリーに熟練した技術を必要とすること, また 母指や示指背側に軽度の知覚麻痺を生じることが あること, さらに皮弁採取部が前腕であり露出す る機会が多く, 整容的には好ましくないてとなど があげられるが, 前記の長所と比較するとこの短 所は問題にならないものと思われる.

\section{3 ）術後における機能障害}

舌・口腔底腫瘍摘出時に再建法を加えることに よって拡大手術が可能となり, 生命に対する予後 の向上が期待できるようになった．次に問題とな るのは機能がどれだけ温存されるかである．前 田 ${ }^{50}$ は広範手術を行った症例では母音（あ行）・ 半母音（や行）以外は発語明瞭度が低くなり，ま た大久保ら ${ }^{51}$ は広範切除の場合, 口腔底全部を含 めて切除したり, 舌可動部の両側にわたる切除を 行うと発語明瞭度は低くなると述べている. 天笠 ら ${ }^{52}$ は切除範囲が大きくなるにつけ発語明瞭度が 低下するが, 再建を行った舌亜全摘例のうち50\% は舌半切除と同様の発語明瞭度が得られたと報告 しており,また咀嚼・曣下に関しては再建の有無 は影響を示さなかったと述べている。また，今野 ら ${ }^{53}$ は舌半切後の構音能は再建法によって影響を 受け, 直接縫縮 $<\mathrm{DP}$ 皮弁 $<$ 筋皮弁 $<$ 遊離前腕皮 弁の順に発語明瞭度は向上していると述べている. この点においても遊離前腕皮弁は舌・口腔底再建 に適していると思われる。

\section{まとめ}

1. 最近経験した代表的な 2 症例を提示し, 舌・ 口腔底悪性腫瘍摘出後の再建法の実際を紹介し, 併せて若干の文献的考察を加えた。
2. 前腕遊離皮弁は, 舌・口腔底悪性腫瘍摘出 後の再建には極めて有用であると思われた。

3. 舌・口腔底悪性腫瘍の再発例 - 進展例に対 し再建法を取り入れた拡大手術が可能となり，好 成績を得ることができるようになった。

\section{参考文献}

1) 山下久雄, 網野三郎, 他 : 舌癌の放射線治療. 癌の 臨床, $7: 195 \sim 210,1961$

2 ) 平野 実, 栗田茂二郎, 他：舌癌の治療. 耳鼻臨床, $72: 333 \sim 343,1979$

3 ) 後藤敏郎：舌癌と舌半側切除. 日耳鼻, $67: 364$ 366,1964

4 ) 田中信三, 川口寿郎, 他: 口腔癌治療の变遷と現状. JONES, $6: 147 \sim 151,1990$

5 ) 大村 進, 石川好美, 他 : 悪性腫瘍切除後の口腔領 域即時再建手術に関する検討一大胸筋皮弁による 40 症例. 日口外誌, $35: 2321 \sim 2334,1988$

6 ) 島岡成和：抗癌物質がラット舌粘膜下毛細血管お よびその周囲組織に及ぼす影響—特に電顕的観察に ついて. 日口外誌, $32: 1581 \sim 1593,1986$

7 ) 西下 明, 木村有朗, 他 : 腫瘍および肺の血管に及 ぼす Bleomycin の影響. 脈管学, 11:23〜26, 1971

8 ) 光嶋 勲, 福田廣志, 他: 顔面および口腔底の再建 に用いた Free radial forearm flap の経験. 形成 外科, $28: 391 \sim 395,1985$

9 ) 高戸 毅, 小野 勇, 他 : Free forearm flap t 用いた再建術. 形成外科, $27: 464 \sim 469,1984$

10）田上 正, 宮沢正純, 他：血管吻合術による遊離前 腕皮弁を用いて口腔癌手術後の即時再建を行った 3 例. 日口外誌, $32: 842 \sim 847,1985$

11）高坂榮一, 福田廣志, 他 : 橈側前腕皮弁・尺側前腕 皮弁による舌再建の経験. 日日外誌，32：1942～1946, 1986

12）道脇幸博, 大野康亮, 他：前腕皮弁による舌再建術 の経験. 日口外誌, $32: 2133 \sim 2139,1986$

13）大野康亮, 吉田 広, 他 : 遊離前腕皮弁による歯肉・ 口腔底部欠損の即時再建の経験. 日口外誌，33：442 $\sim 457,1987$

14) Muhlbauer, W., Herndl. E., et al.: The forearm flap. Plast. Reconstr. Surg., $70: 336 \sim$ 344,1982 
15) Soutar, D.S., Scheker, L. R., et al.: The radial forearm flap : aversatile method for intraoral reconstruction. Brit. J. Plast. Surg., 36 : $1 \sim 8,1983$

16）波利井清紀 : Microsurgery を用いた額面の再建手 術. 現代外科手術学大系, 第 5 巻, 東京: $367 \sim 387$, 1982

17) 梁井 晈, 波利井清紀 : マイクロサージャリ一の基 本手技と器具. 小児外科, $16: 1159 \sim 1164,1984$

18) Song, R., Goa, Y., et al.: The forearm flap. Clin. Plast. Surg., $9: 21 \sim 26,1982$

19）波利井清紀 : Free skin flap の適応とその問題点. 整形・災害外科, $22: 41 \sim 50,1979$

20) McGregor, I. R.: The temporal frap in intraoral cancer : Its use in repairing the post-excisional defect. Brit. J. Plast. Surg., 16 : 318 323,1963

21) Bakamjian, V.Y.: A two-stage method for pharyngo-esophageal reconstruction with a primary pectoral skin flap. Plast. Reconstr. Surg. , 36 : 173 184, 1965

22）松浦秀博, 他: Deltopectoral skin flap による頚 部食道再建の経験. 日外会誌, 71: 934 942, 1970

23) 内田正興 : 頭䅡部癌治療における再建外科の役割. 耳鼻咽喉科領域の最近の進歩, 第 1 版, 医学教育出版 社, 東京, $367 \sim 384,1984$

24 ) 高田和雄, 馬場潤一郎, 他 : 下顎口腔悪性腫瘍切除 後の即時再建術. 東北歯大誌, $10: 88 \sim 93,1983$

25 ) 原 英之, 鷹觜明剛, 他 : 前額皮弁による再建術の 口腔癌への適用. 東北歯大誌, $11: 86 \sim 92,1984$

26) 村上 泰, 行木英生, 他 : 有茎弁による頭頚部腫瘍 の一次的形成手術 (第一報)一口腔内悪性腫瘍に対す る前額皮弁について. 耳喉, 44:85〜91, 1972

27）村上 泰, 大塚 謢, 他: 有茎弁による頭頚部腫瘍 の一次的形成手術 (第三報)一上顎切除における口蓋 の機能再建. 耳喉, 45:161 169, 1973

28）今野昭義, 戸川 清, 他 : 悪性腫瘍切除後の有茎皮 弁による口腔再建術と術後機能. 耳喉, 47: 527〜 536, 1975

29) Quillen, C. G., Shearin, J.C. Jr., et al.: Use of the latissimus dorsi myocutaneous island flap for reconstruction in the head and neck area. Plast. Reconstr. Surg., 62: 113 117, 1978
30) McCraw, J. B., Magee, W. P. Jr., et al. : Uses of the trapezius and sternomastoid myocutaneous flaps in head and neck reconstructon. Plast. Reconstr. Surg., 63 : 49 57, 1979

31) Baeck, S., Biller, H.F., et al.: The pectoralis major myocutaneous island flap for reconstruction of the head and neck. Head Neck Surg., 1 : $293 \sim 300,1979$

32) Arian, S.: The pectoraris major myocutaneous flap : A versatile flap for reconstruction in the head and neck. Plast. Reconstr. Surg., 63 : 73 $\sim 81,1979$

33) Arian, S. : Further experiences with the pectoraris major myocutaneous flap for the immediate repair of defects from excisions of head and neck cancers. Plast. Reconstr. Surg. , 64 : 605 612,1979

34) Withers, E. H. , Franklin, J. D., et al.: Pectoraris major myocutaneous flap ; A new flap in head and neck reconstructon. Amer. J. Surg., $138: 537 \sim 543,1979$

35 ) 坂東正士, 谷川 護, 他 : 頭頚部再建に有効な僧帽 筋・広背筋・大胸筋皮弁による治験. 頭頝部腫痬, 6 : $159 \sim 160,1979$

36) 坂東正士 : 大胸筋を利用した頭䅡部の再建法. 手術, $34: 751 \sim 760,1983$

37) 山本香列, 後藤昭信, 他 : 有茎広背筋皮弁による舌 再建について. 耳鼻, 33:6〜 8, 1987

38 ) 佐々木 (梁井) 晈, 波利井清紀 : 顕微鏡下手術器具. 手術, $36: 1511 \sim 1515,1982$

39 ) 梁井 晈, 波利井清紀, 他 : 頭䅡部領域の再建術一 有茎筋皮弁と遊離筋皮弁の成績の検討. 筋弁および筋 皮弁, 医学教育出版社, 東京, 41 53, 1985

40) Taylor, G.I., Miller, G. D.H., et al.: The free vascularised bone graft a clinical extention of microvascular technique. Plast. Reconstr. Surg., $55:$ 533 544,1975

41 ) 原科孝雄, 後藤 潤, 他 : 遊離小腸移植による口腔 再建術. 耳喉, 57 : 17 20, 1985

42 ) 大野朝也, 大野 敬, 他 : 遊離小腸移植による口腔 癌根治手術後の即時再建. 日口外誌, $36: 1866 \sim 1873$, 1990

43) Black, P.W., Bevin, A.G., et al.: One stage 
palate reconstruction with a free neovascularized jajunal graft. Plast. Reconstr. Surg., 47 : $316 \sim 320,1971$

44) Sasaki, T.M., Baker, H.W., et al.: Free jajunal graft reconstruction after extensive head and neck surgery. Am. J. Surg., 139: 650 653, 1980

45) Souter, P.S., Scheker, L. R.: The redial forearm frap : a versatile method for intra oral reconstruction. Brit. J. Plast. Surg., 36 : $1 \sim 8$, 1983

46 ) 鎌田信悦: 口腔 -中咽頭の再建. 耳鼻臨床, $78: 370$ $\sim 373,1985$

47）波利井清紀：血管吻合による再建外科. 臨床耳鼻咽 喉科頭䅡部外科全書 8-A, 頭頝部腫瘍 (総論). 金原 出版, 東京, $117 \sim 140,1985$
48）高戸 毅, 小野 勇, 他 : Forearm flap 採取部に おける後遺症の検討。日形会誌，4：910～916, 1984

49) Timmons, M.J., Missotten, F.E.M., et al . : Complications of radial forearm flap donor sites. Brit. J. Plast. Surg., 39 : 176 178, 1986

50 ) 前田龍男 : 舌癌治療後の構音機能. 耳鼻, $31: 238 \sim$ 254,1985

51) 大久保 洋, 前田龍男, 他 : 舌癌治療後の構音機能. 音声言語医学, $26: 236 \sim 244,1985$

52 ) 天笠光雄, 岩城 博, 他 : 口腔即時再建症例の治療 成績と術後機能に関する研究．日癌治，23：2591〜 2597, 1988

53 ) 今野昭義, 花沢 秀, 他 : 舌切切除後の舌 -口腔底 再建術と術後の構音機能および咀嚼機能の評価. 耳鼻,

34 : 1393 1408, 1988

\section{抄 録}

\section{閉経後の女性の骨密度におよぼすカルシウム 補給の効果の比較対照試験}

A controlled trial of the effect of calcium supplementation on bone density in postmenoposal women : B. Dawson-Hughes, G.E. Dallal. E.A. Krall,

L. Sadowski, et al The New England Journal of Medicine, 323 : 878 883, 1990

カルシウムに閉経後の女性の骨減少を遅らせる効果 があるかは, はっきり証明されていない. カルシウム 補給が最も必要であると思われる年代の女性は, 概し てカルシウム摂取量が低いという報告が以前にある. そこで閉経後の健康な女性 301 名を 3 群（偽薬服用の 対照群, カルシウム剤 $400 \mathrm{mg} / d a y$ 以下服用, および カルシウム剤400 $650 \mathrm{mg} / d a y$ 服用) に分け, 二重 盲検法により, 脊柱, 大腿骨頸部, および橈骨の骨減 少を観察した. カルシウム剤の検討としては, 炭酸力 ルシウムまたは酒石酸リンゴ酸カルシウムを用い, 一 日当たりカルシウムとして $500 \mathrm{mg}$ を第 3 グループに 摂取させた. 2 年間の観察研究から次の結果を得た。

1) 5 年以内に閉経した女性では脊柱からの骨減少 が急速であり, カルシウムの補給は効果がなかった。 2）6年以上前に閉経した女性と偽薬を服用した女性 の中で, 食餉からのカルシウム摂取量の多い被験者で は骨減少が緩慢であり, 腰部と橈骨の骨密度はほとん ど変化がなかったが, 春柱からの骨減少が認められた。
また, 食餌由来のカルシウムが少ない被験者では, 酒 石酸リンゴ酸カルシウム投与が骨減少を抑制した. 偽 薬対照群との間に次のような有意差が認められた. 大 腿骨頸部の骨密度の変化 (mean $\pm \mathrm{SE}$ ) $0.87 \pm 1.01 \%$ $v s-2.11 \pm 0.93 \%$, 橈骨 $1.05 \pm 0.75 \% v s-2.85 \pm 0.77$ $\%$. 炭酸カルシウムは, 大腿骨頸部と橈骨の骨減少は 抑制したが, 脊柱については効果がなかった。

以上の結果から閉経後の健康な女性では, カルシウ 么の一日摂取量を $800 \mathrm{mg}$ 以上にするてとにより骨減 少を有意に抑制するてとが出来る. 著者らのテストし た dose では, 炭酸カルシウムより酒石酸リンゴ酸カ ルシウムの方が効果があった。

注：ちなみに, 本研究の行われた米国では成人一日 当たりのカルシウム摂取基準值は $800 \mathrm{mg}$ である（日 本では $600 \mathrm{mg}$ ). また, 本研究の被験者はダイレクトメー ルまたはテレビによる募集に応じたボランティアであ り, 倫理面での問題はない. (衛生学 千葉百子) 